\title{
Attitude of Livestock Owners towards Information and Communication technologies (ICTS) Utilization in Southern Rajasthan
}

\author{
Tikam C. Goyal ${ }^{\text {** }}$, Devi Singh Rajput ${ }^{2}$, N. K. Punjabi ${ }^{3}$, \\ Rohitash Kumar ${ }^{1}$ and Harshita Bhumra ${ }^{4}$
}

${ }^{I}$ Department of Veterinary and Animal Husbandry Extension Education, College of Veterinary and Animal Science, Navania, Udaipur-313601, Rajasthan, India

${ }^{2}$ Department of Veterinary and Animal Husbandry Extension Education, College of

Veterinary and Animal Science, Bikaner-334001, Rajasthan, India

${ }^{3}$ Department of Extension Education, School of Agricultural Sciences, JanardhanRai Nagar

Rajasthan Vidhyapeeth, Dabok, Udaipur-313022, Rajasthan, India

${ }^{4}$ Department of Veterinary and Animal Husbandry Extension Education, Apollo College of

Veterinary Medicine, Jaipur-302031, Rajasthan, India

*Corresponding author

\section{A B S T R A C T}

\section{Keywords}

ICTs, Attitude, Livestock owners, Southern Rajasthan

Article Info

Accepted:

18 August 2020

Available Online:

10 September 2020
The present study was conducted in purposely selected Southern Rajasthan. A sample size of 300 livestock owners form Chittorgarh and Nimbahera tehsils of Chittorgarh district and Rajsamand and Nathdwara tehsils of Rajsamand district were selected on the basis of the presence of maximum number of households possessing ICTs for the present investigation. The purpose of the study was to determine the attitude of livestock owners towards utilization ICTs for seeking animal husbandry information. The study findings revealed that majority $(62.33 \%)$ of the respondents had favourable attitude towards ICTs utilization for seeking animal husbandry information. Further, it was found that the level of attitude of respondents towards ICTs utilization was ranged between 42.8 to 87 per cent.

\section{Introduction}

ICTs are technologies offering new ways of communication and exchange of information and knowledge. The term ICT is currently used to denote a wide range of services, applications and technologies using various types of equipment and software, often running over telecommunication network. It includes a range of technologies starting from radio, television, telephone up to modern technologies like mobile phone, multimedia, internet and satellite based communication systems. In recent times, there is a visible shift from old ways of delivering information to modern ways of information delivery 
systems, where ICT is gaining prominence as an engine for economic growth. After the introduction of ICTs in agriculture and livestock sector, extension services have been fast, inexpensive and more significant according to the demand of present time. ICTs are being used in livestock sector in many ways for animal health management, disease diagnosis and control, disease forecasting, feeding of livestock, herd management and for marketing of milk. However, the share of ICTs in livestock development activities is much limited as compare to agriculture (Chargotra and Kanwat, 2006).

The technology which is transferred through traditional methods or approaches of extension system is either disseminated poorly or in delayed manner when it has superseded (Jat, 2017). While, the modern communication technologies when applied to rural areas will help improve communication, increase participation and disseminate information and share knowledge and skills. It is being said that 'cyber extension' would be the major form of technology dissemination in the near future. ICTs help the farming community to improve its productive capabilities and its overall quality of life. A breakthrough in the field of animal husbandry is not possible without an effective communication system to disseminate improved technology and scientific information. ICTs offer opportunities to reach more people and to carry out various functions within extension systems more effectively and efficiently. ICTs provide easy access to local or global information and knowledge and simple channels for two way communication.

\section{Materials and Methods}

The present study was conducted in purposely selected Southern Rajasthan. The study was confined to two districts namely Chittorgarh and Rajsamand which were selected on the basis of the presence of maximum number of households possessing ICTs as per the census report of the GOI, 2011. Two tehsils from each identified district were selected on the similar grounds as followed in the selection of the districts. Keeping the criteria in view, Chittorgarh and Nimbahera tehsils from Chittorgarh district and Rajsamand and Nathdwara tehsils from Rajsamand district were selected for the present investigation. Five villages from each identified tehsil were selected based on the criteria of their location within the $15 \mathrm{~km}$ periphery from the respective tehsil headquarter with CSCs/RGSKs and having considerable number of ICT users. Thus, in total 20 villages were included in the study sample. To select the sample of the respondents, a list of all the families, keeping livestock as source of livelihood and possess at least one ICT, of the identified villages was prepared separately. Keeping the criteria in view, finally 15 respondents were selected randomly from each identified village. Thus, the total sample size for the present investigation was of 300 respondents.

Attitude in the present study was operationalized as 'the degree of positive or negative feelings, opinions, beliefs and actions of livestock owners associated with the use of information and communication technologies for getting animal husbandry information.' To determine the attitude of livestock owners towards ICTs utilization for seeking animal husbandry information, an attitude scale of Kumar and Ratnakar (2011) having positive and negative statements based on Likert technique of summated rating was used with slight modifications. The final scale consisted of 27 statements, of which 16 statements were positive and the rests were negative statements. The respondents were asked to respond to each statement in terms of 
their degree of agreement or disagreement on a five point continuum i.e. 'strongly agree', 'agree', 'undecided', 'disagree' and 'strongly disagree' and rated with weightage of 5, 4, 3, 2 and 1 for positive statements and 1, 2, 3, 4, and 5 to negative statements, respectively. The minimum and maximum possible score ranged between 27 and 135, respectively. Based on the total score obtained, the livestock owners were grouped into three categories i.e. least favourable, favourable and highly favourable by using the mean and standard deviation scores as measures of check. Further, frequency and percentage of respondents in each category of attitude towards ICTs use was calculated and thereafter, the mean score and mean per cent score for each statement was worked out individually and ranked accordingly.

\section{Results and Discussion}

Attitude of livestock owners towards ICTs utilization for seeking animal husbandry information

Thurstone (1946) defined attitude as 'the degree of positive and negative feelings associated with some psychological objects towards which people differ in varying degrees. The attitude of an individual plays a significant role in the adoption or rejection of technology/innovation. The success of any development programme to a great extent depends on the type of attitude possessed by clientele system towards the object in question. Information and communication technologies overcome many of the limitations of traditional transfer of technology methods. ICT have proved its potential in terms of accuracy, low cost, speed, quality, quantity and timeliness.

A perusal of data in Table 1 indicates that out of total 300 sampled respondents 187 $(62.33 \%)$ had favourable attitude towards ICT use for seeking information about animal husbandry. Whereas, $59(19.67 \%)$ of the total sample had least favourable attitude while the remaining $54(18 \%)$ of the total respondents possessed highly favourable attitude towards ICTs utilization for access and application of animal husbandry information.

A critical observation to the data vividly shows that a fair majority $(80.33 \%)$ of respondents fell in the category of favourable and highly favourable attitude towards ICT for seeking and utilizing animal husbandry information. It is a useful reminder to the development agencies and organizations to harness the positivity of mindsets hold by the respondents towards ICT use in the study area.

Table.1 Attitude of livestock owners towards ICTs utilization for seeking animal husbandry information

\begin{tabular}{|l|c|l|c|c|}
\hline Attitude & Mean \pm SD & Category & \multicolumn{2}{|c|}{$\begin{array}{c}\text { Total respondents } \\
(\mathbf{n = 3 0 0})\end{array}$} \\
\cline { 3 - 5 } & & & $\begin{array}{c}\text { Frequency } \\
(\mathbf{f})\end{array}$ & $\begin{array}{c}\text { Percentage } \\
(\%)\end{array}$ \\
\hline $\begin{array}{l}\text { Attitude } \\
\text { towards ICTs }\end{array}$ & $98.22 \pm 15.65$ & Least favourable (below 84) & 59 & 19.67 \\
\cline { 3 - 5 } & & Favourable (84-114) & 187 & 62.33 \\
\cline { 3 - 5 } & & Highly favourable (above 114) & 54 & 18 \\
\hline
\end{tabular}


Table.2 Item-wise attitude of livestock owners towards ICTs utilization for seeking animal husbandry information

\begin{tabular}{|c|c|c|c|c|}
\hline \multirow[t]{2}{*}{ S. No. } & \multirow[t]{2}{*}{ Statement } & \multicolumn{3}{|c|}{$\begin{array}{l}\text { Total respondents } \\
\quad(\mathbf{n}=\mathbf{3 0 0})\end{array}$} \\
\hline & & MS & MPS & Rank \\
\hline 1. & $\begin{array}{l}\text { ICTs provide possible solutions of problems related to animal } \\
\text { husbandry }\end{array}$ & 4.35 & 87 & I \\
\hline 2. & ICTs cannot meet location specific needs of livestock owners & 3.61 & 72.2 & $\mathrm{XV}$ \\
\hline 3. & ICTs are potential tools for quick reach to the needy livestock owners & 4.29 & 85.8 & III \\
\hline 4. & Farmers' feedback is fast through ICTs than traditional tools & 3.80 & 76 & XIII \\
\hline 5. & Illiteracy will not deter livestock farmers in availing ICT services & 3.88 & 77.6 & XI \\
\hline 6. & It is possible to get solution of personalized problems through ICTs & 3.72 & 74.4 & XIV \\
\hline 7. & $\begin{array}{l}\text { ICT based extension services assist the livestock farmer in scientific } \\
\text { planning }\end{array}$ & 3.87 & 77.4 & XII \\
\hline 8. & ICT services is a distant dream for resource poor livestock owners & 3.11 & 62.2 & XXII \\
\hline 9. & $\begin{array}{l}\text { Livestock owners can get remunerative prices of their produce } \\
\text { through ICT based market intelligence }\end{array}$ & 3.45 & 69 & XVIII \\
\hline 10. & Expert advice through ICT makes the livestock owners enterprising & 4.31 & 86.2 & II \\
\hline 11. & All kinds of information exchange are possible through ICTs & 3.35 & 67 & $\mathrm{XX}$ \\
\hline 12. & $\begin{array}{l}\text { Existing infrastructure of ICTs is not enough to meet the needs of the } \\
\text { livestock farming community }\end{array}$ & 2.58 & 51.6 & $\mathrm{XXV}$ \\
\hline 13. & Only resourceful livestock owners can harness the benefits of ICTs & 3.17 & 63.4 & XXI \\
\hline 14. & $\begin{array}{l}\text { Access and availability of information centre at village level is a boon } \\
\text { to livestock owners }\end{array}$ & 3.99 & 79.8 & VIII \\
\hline 15. & $\begin{array}{l}\text { Phone-in-live with animal husbandry experts provide firsthand } \\
\text { information on queries }\end{array}$ & 3.80 & 76 & XIII \\
\hline 16. & ICTs would solve all the problems of livestock owners & 3.90 & 78 & $\mathrm{X}$ \\
\hline 17. & $\begin{array}{l}\text { Disease outbreak warning system through ICT facilitate livestock } \\
\text { owners to take timely preventive measures }\end{array}$ & 3.53 & 70.6 & XVII \\
\hline 18. & ICT extension services minimize the personal extension contact & 3.10 & 62 & XXIII \\
\hline 19. & $\begin{array}{l}\text { ICT based extension services are good alternative to the present } \\
\text { extension system }\end{array}$ & 2.93 & 58.6 & XXIV \\
\hline 20. & $\begin{array}{l}\text { ICT based extension services provide new opportunity to build a } \\
\text { skilled and knowledge community of livestock farmers }\end{array}$ & 3.92 & 78.4 & IX \\
\hline 21. & $\begin{array}{l}\text { Though ICT is a valuable tool, but it will never influence farmers' } \\
\text { own decision making }\end{array}$ & 2.14 & 42.8 & XXVI \\
\hline 22. & $\begin{array}{l}\text { ICT application in animal husbandry is more of propaganda and less } \\
\text { of reality }\end{array}$ & 3.37 & 67.4 & XIX \\
\hline 23. & I like to use ICT tools for seeking information on animal husbandry & 4.21 & 84.2 & IV \\
\hline 24. & Use of ICT for seeking information is a lazier time work & 3.56 & 71.2 & XVI \\
\hline 25. & ICT application reduces the socio-cultural barriers & 4.08 & 81.6 & VI \\
\hline 26. & Use of ICT tools leads to modernization & 4.07 & 81.4 & VII \\
\hline 27. & ICT uses are economically feasible & 4.10 & 82 & V \\
\hline
\end{tabular}

MS = Mean score MPS = Mean per cent Score 
The results of the study are in conformity with the results of Reddy and Reddy (1997), Dhaka and Chayal (2010), Devaraja (2011), Raghuprasad et al., (2012), Baig (2015), Kabir (2015), Jat (2017) and Rajoria et al., (2018). The findings of the study are somewhat different with results of Panda et al., (2019) who reported that majority of the farmers were having a neutral attitude towards the information and communication technology.

Item-wise attitude of livestock owners towards ICTs utilization for seeking animal husbandry information

The data presented in Table 2 indicate that a very high proportion of the respondents (MPS 87) have reflected positive attitude and agreed that 'ICTs provide possible solutions of all problems related to animal husbandry', which was ranked first by the respondents. Further, the respondents viewed the statement favourably and agreed that 'expert advice obtained through ICT makes the livestock owners enterprising' (MPS 86.2) and assigned second rank in the rank order.

The respondents have responded favourably to the statement about 'ICTs as potential tools for quick reach to needy livestock owners'(MPS 85.8) with third rank. Further, the 'ICT tools for seeking information on animal husbandry' was favourably viewed by majority of respondents (MPS 84.2) and was ranked fourth in the rank order. It can be seen from data that quite a big number of respondents (MPS 82) favourably responded to the statement that 'ICT uses are economically feasible' and ranked fifth accordingly. Similarly, a highly significant number of respondents (MPS 81.6) strongly believed that 'ICT application reduces the socio-cultural barriers' and as such was ranked sixth in rank order. 'Use of ICT tools leads to modernization' was again rated favourably by large number of respondents (MPS 81.4) and accorded seventh rank. The statement 'access and availability of information centre at village level as a boon to the livestock owners' was favoured by a large proportion of subjects (MPS 79.8) and ranked eighth in order. Similarly, a good number of respondents (MPS 78.4) favoured and agreed to a statement which states that 'ICT based extension services provide new opportunity to build a skilled and knowledge community'. Further, more than three-fourth of the total livestock owners possessed a favourable attitude and stated that 'ICT would solve all the problems of livestock owners' as such was accorded tenth rank in the rank order. A favourable response was received for the statement stating that 'illiteracy will not deter livestock farmers in availing ICT services' (MPS 77.6) with eleventh rank. It was followed by attitude statements which state that 'ICT based extension services assist the livestock farmers in scientific planning'(MPS 77.4) and 'farmers' feedback is fast through ICTs than traditional tools' (MPS 76) with twelfth and thirteenth rank, respectively.

Furthermore, the attitude statements indicating the "possibility of getting solution of personalized problems through ICTs' (MPS 74.4), 'inability of ICT to meet the location specific needs of livestock owners' (MPS 72.2), 'use of ICT is a leisure time work' (MPS 71.2) and 'disease outbreak warning system through ICT facilitates timely preventive measures' (MPS 70.6) were favourably viewed by a considerable number of respondents and were placed at fourteenth, fifteenth, sixteenth and seventeenth rank, respectively. Likewise, the statement 'livestock owners can get remunerative price of their produce through ICT based market intelligence' (MPS 69) scored eighteenth rank in the order. Next to this was the attitude statements viz. 'ICT application in animal 
husbandry is more of propaganda and less of reality' (MPS 67.4), 'all kinds of information exchanges are possible through ICTs' (MPS 67), 'resourceful livestock owners only can harness the benefits of ICTs' (MPS 63.4), 'ICT services are still a distant dreams for resource poor livestock owners' (MPS 62.2), 'ICT extension services minimize the personal extension contacts' (MPS 62) were the statements favoured but by relatively less number of subjects and as such were assigned lower ranks from nineteen to twenty-two in the rank order, respectively.

Lastly, the least favoured attitude statements as expressed by the livestock owners whose mean present score ranged from 60 to 40 were 'ICT based extension services are good alternative to the present extension system', 'insufficient ICT infrastructure to meet the needs of livestock farmers' community' and 'ICT is a valuable tool but never influence farmers' decision making' and therefore were assigned last ranks from twenty-three to twenty-seven in the rank hierarchy.

An in depth understanding of the results pertaining to the attitude of livestock owners towards ICTs reveals that livestock owners in the study area possessed an overall favourable attitude towards the application of ICTs. The reflection of favourable attitude towards ICTs by the livestock owners was not unexpected because of increasing exposure, access and availability of ICTs by government and nongovernment organizations, wherein the farmers are directly connected through ICT.

In addition to this the higher knowledge of ICT tools observed among the study respondents might have contributed in shaping their attitude towards positive and favourable side. It seems that livestock owners of the study area have realized the benefits and importance of ICT during the contemporary time and that too might have impacted their mindsets towards favourable attitude. These reasons coupled together might have led to favourable attitude which is reflected in the study results.

The inferences therefore can be drawn that there exists an ample opportunity for increasing use of ICTs by livestock owners for improvement in animal husbandry and for their own well-being.

The study findings are in line with the findings of Dhaka and Chayal (2010), Devaraja (2011), Raghuprasad et al., (2012), Baig (2015), Kabir (2015), Singh et al., (2017) and Rajoria et al., (2018) who reported that majority of the farmers had favourable attitude towards ICTs utilization for seeking farm related information.

\section{References}

Anonymous, 2011.Census Info India.Houses, Household Amenities and Assets.Govt. of India.

Baig, R. 2015. Extent of utilization of ICT tools among field veterinarians of Andhra Pradesh.M.V.Sc. Thesis, Department of Veterinary and Animal Husbandry Extension Education, College of Veterinary Science, Sri Venkateswara Veterinary University, Tirupati.

Chargotra, M. and Kanwat, M. 2006.Use of information technology in agriculture. Agriculture Today. IX(7): 17-19.

Devaraja, S.C. 2011. A study on knowledge and attitude of farmers using ICT tools for farm communication. M.Sc. Thesis, Department of Agricultural Extension, University of Agricultural Sciences, GKVK, Bengaluru.

Dhaka, B.L. and Chayal, K. 2010. Farmers' experience with ICTs on transfer of technology in changing agri-rural environment. Indian Research Journal 
of Extension Education. 10: 114-118.

Jat, J.R. 2017.Role of information and Communication Technologies (ICTs) in transfer of agricultural technology among the farmers of southern Rajasthan. Ph.D. Thesis, Department of Extension Education, RCA, MPUAT, Udaipur, Rajasthan.

Kabir, K.H. 2015.Attitude and level of knowledge of farmers on ICT based farming. European Academic Research. 2(10): 13177-13196.

Kumar, P. Ganesh and Ratnakar, R. 2011. A Scale to measure farmer's attitude towards ICT-based extension services. Indian Research Journal of Extension Education. 11(1): 109-112.

Panda, S., Devi, Y.L., Das, L., Mondal, S., Pradhan, K. and Pal, P.K.2019. Sociopersonal determinants of farmers' attitude towards information and communication technology (ICT). Agricultural Science Digest. 39(4): 328331.

Raghuprasad, K.P., Devaraja, S.C. and Gopala, Y.M. 2012. Attitude of farmers towards utilization of Information
Communication Technology (ICT) tools in farm communication. Research Journal of Agricultural Sciences. 3(5): 1035-1037.

Rajoria, S.,Rewani, S.K., Singh, V., Singodia, M., Nanda, B.and Bhumra, H. 2018. Attitude of livestock farmers towards the ICT based livestock extension services in Jaipur district of Rajasthan, India. Int. J. Curr. Microbiol. App. Sci. 7(2): 1014-1021.

Reddy, P.R. and Reddy, S.J. 1997. Farm Broadcasts: Listening behaviour of farmers. Harita Publishing House, Hyderabad. Pp. 37-91.

Singh, A.S., Thomas, S.S. and Douglas, K. 2017. Knowledge, perception and challenges of ICT tools adoption to improve marketing of vegetable produce: case study of vegetable farmers in Manzini region, Swaziland. International Journal of Current Agricultural Sciences. 7(3): 180-189.

Thurston, L.L. 1946. The measurement of attitude. American Journal of Sociology. 52: $39-50$.

\section{How to cite this article:}

Tikam C. Goyal, Devi Singh Rajput, N. K. Punjabi, Rohitash Kumar and Harshita Bhumra. 2020. Attitude of Livestock Owners towards Information and Communication technologies (ICTS) Utilization in Southern Rajasthan. Int.J.Curr.Microbiol.App.Sci. 9(09): 2451-2457. doi: https://doi.org/10.20546/ijcmas.2020.909.305 